\title{
Utilization of Shatavari meal in poultry feed: an overview
}

\begin{abstract}
Over the past few years, one of the most promising approaches has been the exploration of the power of the nature i.e. herbs, shrubs and trees. Shatavari (Asparagus racemosus) is a woody climber and the roots are finger-like and clustered. Shatavari contains steroid saponins. The present review reflects on the few studies undertaken on shatavari meal to modulate growth and immunity in chicken. However, there is a need for comprehensive studies in different species of poultry validating its dose and mode of action in poultry.
\end{abstract}

Keywords: Shatavari, poultry, feed, growth, immunity
Volume 3 Issue 6 - 2018

\author{
PK Shukla, BK Yadav, A Bhattacharyya \\ Department of Poultry Science, College of Veterinary Science \\ and Animal Husbandry, India
}

Correspondence: PK Shukla, Department of Poultry Science, College of Veterinary Science and Animal Husbandry, DUVASU, Mathura, UP, India, Email pksmethura@yahoo.co.in

Received: August 0I, 20I8 | Published: November 26, 2018

\section{Introduction}

In the recent past, efforts have been made to counteract the adverse effects of various levels of stress and augment the production potential in poultry by using herbs possessing therapeutic potential. Number of herbal medicines has been studied on poultry species such as the herbal growth promoters which optimize hepatic functions of the birds. Efforts have been made to study the effect of dietary supplementation of Shatavari (Asparagus racemosus) root powder in the diet of broiler chicks to augment the growth of broilers. ${ }^{1,2}$ Shatavari (Asparagus racemosus) also known as the "Queen of herbs" is a woody climber growing 1-2 $\mathrm{m}$ in height and the roots are finger-like and clustered. The leaves are like pine needles, small and uniform and the inflorescence has tiny white flowers in small spikes. The genus Asparagus includes about 300 species around the world. The genus is considered to be medicinally important because of the presence of steroidal saponins and sapogenins in various parts of the plant. Out of the 22 species of Asparagus recorded in India, Asparagus racemosus is the one most commonly used in traditional medicine. This plant belongs to Liliaceae family, common at low altitudes in shade and in tropical climates throughout India, Asia, Australia and Africa. Shatavari has been mentioned in Ayurvedic texts like the Charak Samhita, Susruta Samhita and Astanga Samgraha. ${ }^{3,4}$ Shatavari possesses nutritive, antistress, adaptogenic, immunomodulatory, galactogogue, anabolic and performance enhancing properties and are used in various medicinal preparations..$^{5-9}$ According to recent chemical investigations, shatavari contains four steroid saponins: Shatavarins 1 to 4 . Shatavarin 1 is the major glycoside of sarsasapogenin, the sugar moieties being 3 glucose and 1 rhamnose. Shatavari 4 is structurally related to shatavarin 1 and contains 2 glucose and 1 rhamnose. Overall Shatavari is a soothing tonic, alternative demulcent, refrigerant. It nourishes and rejuvenates the tissue, promotes vitality and strength. It is bitter, emollient, cooling, nervine, appetizer and astringent. It is used for diseases of blood and nervous disorders as well as general debility.

\section{Discussion}

\section{Properties}

Shatavari has been mentioned in Ayurvedic texts like the Charak Samhita and Susruta Samhita, and Astanga Samgraha. ${ }^{3,4}$
Kashyap Samhita has evidently stated that Shatavari promotes maternal health and noted its meticulous use as a galactagogue (enhances breast milk secretion in lactating mothers). Ayurveda has called Shatavari the Queen of herbs and is the primary herb recommended for female health. They exhibit immuno-modulatory activities. The root of Asparagus racemosus (commonly called 'Satavar') possesses antidiarrhoeal, anti-ulcerative, anti-spasmodic, aphrodisiac, galactogogue and other properties and has therefore gained its importance in Ayurveda, Siddha and Unani systems of medicine. $^{10}$

Asparagus root possesses aphrodisiac, demulcent, general tonic, diuretic, anti-inflammatory, antiseptic, anti-oxidant and antispasmodic properties. Regular use of asparagus root treats infertility, impotence, leucorrhea, menopause syndromes, hyperacidity and certain infectious diseases such as herpes and syphilis. It is also useful in treatment of epilepsy, kidney disorders, chronic fevers, excessive heat, stomach ulcers and liver cancer, increases milk secretion in nursing mothers and regulates sexual behaviors.

These roots find use in various medicinal preparations. ${ }^{89}$ The stem is woody, climbing, whitish grey or brown colored with small spines. The plant flowers during February-March leaving a mild fragrance in its surrounding and by the end of April, fruits can be seen with attractive red berries. Asparagus racemosus is a plant used in traditional Indian medicine. ${ }^{11}$

The root powder of Asparagus racemosus is used as herbal feed additive/supplement in poultry feed. Shatavari augments the appetite and stimulates the liver. The root is used to prepare medicine.

\section{Chemical constituents of Shatavari}

The major active constituents of Asparagus racemosus are steroidal saponins named as shatavarin I and shatavarin IV which are present in the roots. Shatavarins are the glycoside of sarsasapogenin which are generally occurring in two types of skeletons furostanols and spirostanols rhamnose. 8-methoxy- 5, 6, 4'-trihydroxyisoflavone, a new isoflavone was isolated by roots of Asparagus racemosus. A noval oligospirostanosid $\quad 1,3-O$ - $[\alpha$-L-3-rhamnopyronosyl- $(1 \rightarrow 2)-\alpha$-Lrhamnopyronosyl $(1 \rightarrow 4)-O-\beta$-D glycopyranosyl] $25(S)-5 \beta$ Spirostan$3 \beta$-ol also known as immunoside was isolated and it was biologically evaluated as an immunomodulatory agent. ${ }^{12}$ Chemical structure 
of steroidal saponines of Asparagus racemosus has antioxidant compound named Racemofuran, together with known compounds asparagamine A, and racemosol. ${ }^{13}$ Three steroidal saponins namely Racemosides A, B and C were isolated from the methanolic extract of fruit of Asparagus racemosus..$^{14}$ Isolation and structural clarification of Asparinins, Asparosides, Curillins, Curillorides and shavatarins was performed along with isolation of a new steroidal saponin shatavarin $\mathrm{V}$ from Asparagus racemosus powdered roots. Five steroidal saponins VI-X together with five known saponins Shatavarin I, Shatavarin IV, Shatavarin V, Schidegerasaponin D5 Immunside were isolated from Asparagus racemosus roots. ${ }^{15}$

\section{Body weight}

It had been reported that supplementation of Shatavari powder @ $10 \mathrm{~kg} /$ ton and Aswagandha powder@ $@ 5 \mathrm{~kg} /$ ton to basal diet showed significantly $(\mathrm{P}<0.05)$ higher body weight. ${ }^{2}$ Herbal feed additive prepared from whole plants of Ashwagandha [Withania somnifera], Shatavari [Asparagus racemosus] and Kapikachhu [Mucuna pruriens] (50:25:25) and mixed as powder to basal diet @ 2\% resulted in significant higher $(\mathrm{P}<0.05)$ body weight at $6^{\text {th }}$ week in the treated group as compared to control group. ${ }^{16}$ It had been observed that there was significantly $(\mathrm{P}<0.01)$ higher live body weight in $0.5 \%, 1 \%$ and $1.5 \%$ Asparagus racemosus root powder supplemented groups as compared to control broilers. ${ }^{17}$

\section{Body weight gain}

There was significantly $(\mathrm{P}<0.05)$ higher body weight gain in $0.25 \%$ and $0.5 \%$ Asparagus racemosus (Shatavari) root powder supplemented groups as compared to control groups in broilers. ${ }^{18}$ It was observed that there was observed significantly $(\mathrm{P}<0.05)$ higher body weight gain in $0.5 \%$ and $1 \%$ Asparagus racemosus (Shatavari) root powder supplemented groups as compared to control in broilers. ${ }^{19}$ Further, it had been observed significantly $(\mathrm{P}<0.05)$ higher body weight gain in $0.5 \%$ and $1 \%$ Asparagus racemosus (Shatavari) root powder supplemented groups as compared to control in broilers. ${ }^{20}$ It had been reported that supplementations of Shatavari powder (a) $10 \mathrm{~kg} / \mathrm{ton}$ and Aswagandha powder @ $5 \mathrm{~kg} /$ ton to basal diet showed significantly $(\mathrm{P}<0.05)$ higher body weight gain. ${ }^{2}$

\section{Feed consumption}

It was reported that the cumulative feed consumption at sixth week of age was better in $0.5 \%$ and $1 \%$ Asparagus racemosus (Shatavari) root powder supplemented groups as compared to control in broilers. ${ }^{19}$ It was observed that the average feed consumption of $0 \%$ (control) and $0.25 \%$ Asparagus racemosus (Shatavari) root powder supplemented group was higher as compared to $0.5 \%$ shatavari supplemented group in broilers. ${ }^{18}$ It had been indicated that feed consumption was significantly $(\mathrm{P}<0.05)$ higher in $1.5 \%$ Shatavari root powder supplemented group as compared to other groups of broiler birds. ${ }^{21}$

\section{Feed conversion ratio}

It had been reported that feed conversion ratio was significantly $(\mathrm{P}<0.05)$ lower in Shatavari root powder as compared to control group in broilers. ${ }^{21}$ It was noted that supplementation of Shatavari root powder at $0.5 \%, 1 \%$ and $1.5 \%$ resulted in better feed conversion efficiency. ${ }^{17}$ It was reported that herbal feed additive prepared from whole plants of Ashwagandha, Shatavari and Kapikachhu and mixed as powder to basal diet @ 2\% resulted in better feed conversion ratio at $6^{\text {th }}$ week as compared to control group. ${ }^{16}$

\section{Immunocompetence traits}

It was noted the immuno-modulatory effects of Asparagus racemosus extract treated feed which resulted in significant $(\mathrm{P}<0.01)$ higher humoral and cell mediated immune responses of the birds compared to control group. ${ }^{22}$ It was reported that the broilers treated with Asparagus racemosus alone as well as in different combinations with Sida cordifoliawas and Levamisole starting from $28^{\text {th }}$ day of age for 2 weeks had higher antibody production than normal due to more stimuli to the immune system. ${ }^{23}$

\section{Biochemical attributes}

It was reported blood glucose, calcium, and phosphorus were significantly $(\mathrm{P}<0.05)$ higher in Shatavari supplemented groups as compared to control group and highest in $1.5 \%$ Shatavari powder in broilers. Blood urea nitrogen and creatinine was found significantly $(\mathrm{P}<0.05)$ lower in Shatavari supplemented groups as compared to control. ${ }^{21}$ It had been reported that supplementation of Shatavari root powder at $0.5 \%, 1 \%$ and $1.5 \%$ level resulted in significantly $(\mathrm{P}<0.01)$ higher $\mathrm{Hb}$, total serum protein, albumin and globulin value in chicken as compared to control. ${ }^{17}$ It had been reported that the Shatavari powder and vitamin E was added to the basal diet@ $0 \%$ and $0 \mathrm{mg} / \mathrm{kg}$ feed, $1 \%$ and $0 \mathrm{mg} / \mathrm{kg}$ feed, $1.5 \%$ and $0 \mathrm{mg} / \mathrm{kg}$ feed, $0 \%$ and $200 \mathrm{mg} /$ $\mathrm{kg}$ feed, $1 \%$ and $200 \mathrm{mg} / \mathrm{kg}$ feed, $1.5 \%$ and $200 \mathrm{mg} / \mathrm{kg}$ feed. There was a significant $(\mathrm{P}<0.05)$ increase in hematological parameters like total erythrocyte counts, hemoglobin, packed cell volume, mean corpuscular volume, mean corpuscular $\mathrm{Hb}$ and mean corpuscular $\mathrm{Hb}$ concentration in Shatavari and vitamin $\mathrm{E}$ treated groups than control group. Total serum protein, albumin, globin were significantly $(\mathrm{P}<0.05)$ higher and cholesterol, alanine aminotransferase and aspartate aminotransferase were significantly $(\mathrm{P}<0.05)$ lower in shatavari and vitamin $\mathrm{E}$ treated groups than control group. ${ }^{24}$

\section{Carcass characteristics}

It had been reported that there was a significantly $(\mathrm{P}<0.05)$ higher percentage of dressing yield in $0.25 \%$ and $0.5 \%$ Asparagus racemosus (Shatavari) root powder supplemented groups as compared to control in broilers. ${ }^{18}$ Further, it had been reported that the powder of Shatavari and vitamin $\mathrm{E}$ was added to the basal diet $@ 0 \%$ and $0 \mathrm{mg} / \mathrm{kg}$ feed, $1 \%$ and $0 \mathrm{mg} / \mathrm{kg}$ feed, $1.5 \%$ and $0 \mathrm{mg} / \mathrm{kg}$ feed, $0 \%$ and $200 \mathrm{mg} / \mathrm{kg}$ feed, $1 \%$ and $200 \mathrm{mg} / \mathrm{kg}$ feed, $1.5 \%$ and $200 \mathrm{mg} / \mathrm{kg}$ feed. Carcass quality and organ weight was significantly $(\mathrm{P}<0.05)$ higher in treatment groups as compared to control, observed highest in Shatavari $1.5 \%$ and $200 \mathrm{mg} / \mathrm{kg}$ feed vitamin- E group of broiler chickens. Therefore, it was concluded that supplementation of Shatavari $1.5 \%$ and 200 $\mathrm{mg} / \mathrm{kg}$ feed vitamin- E was observed more beneficial to remove cold stress and improve growth performance, carcass quality and organ weight of broiler birds. ${ }^{24}$

\section{Conclusion}

Studies have been undertaken to assess the effect of Shatavari root meal on the growth, immunity, blood biochemical attributes and carcass quality characteristics of broilers. However, detail studies are necessary to assess the efficacy of Shatavari root meal at various levels at various levels on the productive performance and immunity of different varieties of chicken.

\section{Acknowledgments}

None. 


\section{Conflicts of interest}

Author declares that there is no conflict of interest.

\section{References}

1. Sharma S, Dahanukar S, Karandikar SM. Effects of long term administration of the roots of Ashwagandha (Withania somnifera) and Shatavari (Asparagus racemosus) in rats. Indian Drugs. 1986;23:133-139.

2. Mane AG, Kulkarni AN, Korake RL, et al. Effect of supplementation of Ashwagandha (Withania somnifera) and Shatavari (Asparagus racemosus) on growth performance of broilers. Res J Anim Husbandry and Dairy Sci. 2012;3:94-96.

3. Singh GK, Garabadu D, Muruganandam AV, et al. Antidepressant activity of Asparagus racemosus in rodent models. Pharmacol Biochem Behav. 2009;91(3):283-290.

4. Raghav A, Kasera PK. Seed germination behavior of Asparagus racemosus (Shatavari) under in-vivo and in-vitro condition. Asian J plant Sci and res. 2012;2:409-413.

5. Kamat JP, Krutin KB, Thomas PA, et al. Antioxidant properties of Asparagus recemosus against damage induced by gamma-radiation in rat liver mitochondria. J Ethnopharmacol. 2000;71:425-435.

6. Chopra RN, Naiyar SL, Chopra IC. Glossary of Indian Medicinal Plants. CSIR. 1956;28:150-176.

7. Chopra RN, Naiyar SL, Chopra IC. Chopra's indigenous drugs of India. Calcutta: Dhu and Sons Pvt Ltd; 1958. p. 496-560.

8. Mandal SC, Nandy A, Pal M, et al. Evaluation of antibacterial activity of Asparagus racemosus wild root. Phytother Res. 2000;14(12):118-119.

9. Bopana N, Saxena S. Asparagus racemosus-Ethnopharmacological evaluation and conservation needs. J of Ethnopharmacol. 2007;110:1-15.

10. Nadkarni AK. Indian Materia Medical. $3^{\text {rd }}$ edn. India: Bombay, Popular Book Depot; 1954. p. 53-155.

11. Goyal RK, Singh J, Lal H. Asparagus racemosus-An update. Indian J Medical Sci. 2003;57(9):408-414.

12. Handa SS, Suri OP, Gupta VN, et al. Process for the isolation of novel oligospirostanoside. US Patent. 2003;670:459.

13. Wiboonpun N, Phuwapraisirisan P, Tip-pyang S. Identification of antioxidant compound from Asparagus racemosus. Phytother Res. 2004;8:771-773

14. Hayes PY, Jahidin AH, Lehmann R, et al. Asparinins, asparosides, curillins, curillosides and shavatarins: structural clarification with the isolation of shatavarin V, a new steroidal saponin from the root of Asparagus racemosus. Tetrahedron Lett. 2006;47:8683-8687.

15. Hayes PY, Jahidin AH, Lehmann R, et al. Steroidal saponins from the roots of Asparagus racemosus. Phytochem. 2008;69:796-804.

16. Pandey NK, Singh DP, Ram N. Broiler characteristics, sensory qualities. And economics efficiency in Vencobb - 400 chicks supplemented with a conjugated herbal feed additive in diet. Anim Sci Reporter. 2013;7:128 132 .

17. Rekhate DH, Ukey S, Leena MN, et al. Effect of dietary supplementation of Shatavari (Asparagus racemosus wild) on haematobiochemical parameters of broilers. Vet World. 2010;3:280-281.

18. Dahale GS, Wankhede SM, Kale VR. Growth performance, serum biochemical profile and carcass quality of broiler chickens fed diets supplemented with Shatavari (Asparagus racemosus) root powder. Indian J Anim Nutr. 2014;31:166-171.

19. Gaikwad DS, Manwar SJ, Nage SP, et al. Effect of supplementation of shatavari root and amla fruit powder on performance of broilers. Indian J Poult Sci. 2014;49:334-335.

20. Gaikwad DS, Nage SP, Chavan SD, et al. Effect of supplementation of Shatavari root powder on broiler characteristics and economics of Vencobb-400 chicks. Int Quart J Env Sci. 2015;7:259-262.

21. Kant S, Ali N, Chandra G, et al. Effect of shatavari and vitamin E on growth performance, biochemical profile and dressing percentage of broilers during winter season. Indian J Poult Sci. 2015;50:158-162.

22. Kumari R, Tiwary BK, Prasad A, et al. Asparagus racemosus wild. Root Extract as herbal nutritional supplement for poultry. Global J Res in Med Plants and Ind Med. 2012;1:1-6.

23. Tekade SH, Mode SG, Waghmare SP. Effect of Asparagus recemosus, Sida cordifolia and Levamisole on immunological parameters in experimentally induced immunosuppressed broilers. Vet World. 2008;1:49-50.

24. Kant S, Ali N, Chandra G, et al. Effect of shatavari and vitamin E on hemato-biochemical profile of broilers during winter season. Vet World. 2014;7:948-951. 